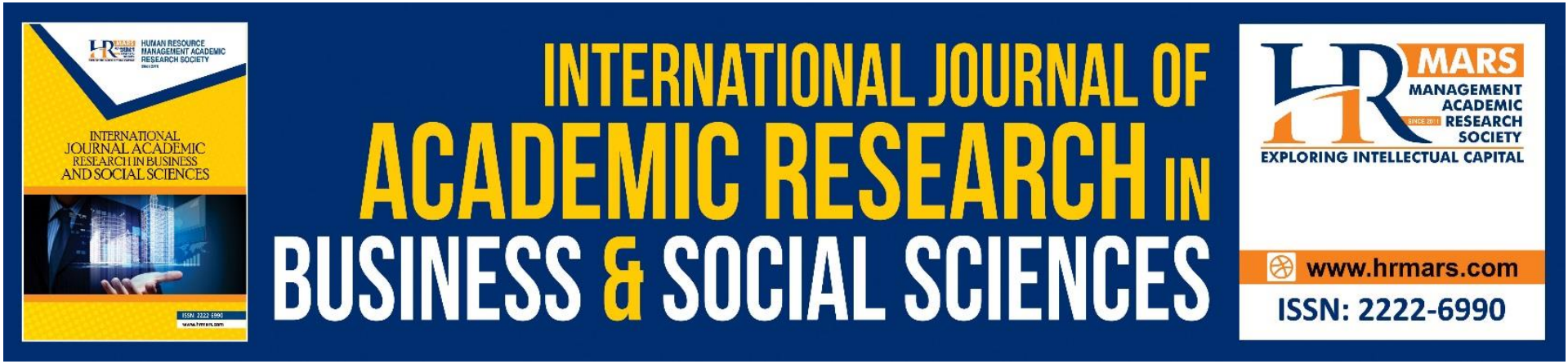

\title{
Language Learning Strategies among Undergraduates During Online Learning in Covid-19 Pandemic in A Public University in Malaysia
}

Amizan Azim Ramli, Ashinida Aladdin

To Link this Article: http://dx.doi.org/10.6007/IJARBSS/v11-i12/11960

DOI:10.6007/IJARBSS/v11-i12/11960

Received: 09 October 2021, Revised: 12 November 2021, Accepted: 25 November 2021

Published Online: 21 December 2021

In-Text Citation: (Ramli \& Aladdin, 2021)

To Cite this Article: Ramli, A. A., \& Aladdin, A. (2021). Language Learning Strategies among Undergraduates During Online Learning in Covid-19 Pandemic in A Public University in Malaysia. International Journal of Academic Research in Business and Social Sciences, 11(12), 2452-2470.

Copyright: @ 2021 The Author(s)

Published by Human Resource Management Academic Research Society (www.hrmars.com)

This article is published under the Creative Commons Attribution (CC BY 4.0) license. Anyone may reproduce, distribute, translate and create derivative works of this article (for both commercial and non0-commercial purposes), subject to full attribution to the original publication and authors. The full terms of this license may be seen at: http://creativecommons.org/licences/by/4.0/legalcode

Vol. 11, No. 12, 2021, Pg. 2452- 2470

Full Terms \& Conditions of access and use can be found at http://hrmars.com/index.php/pages/detail/publication-ethics 


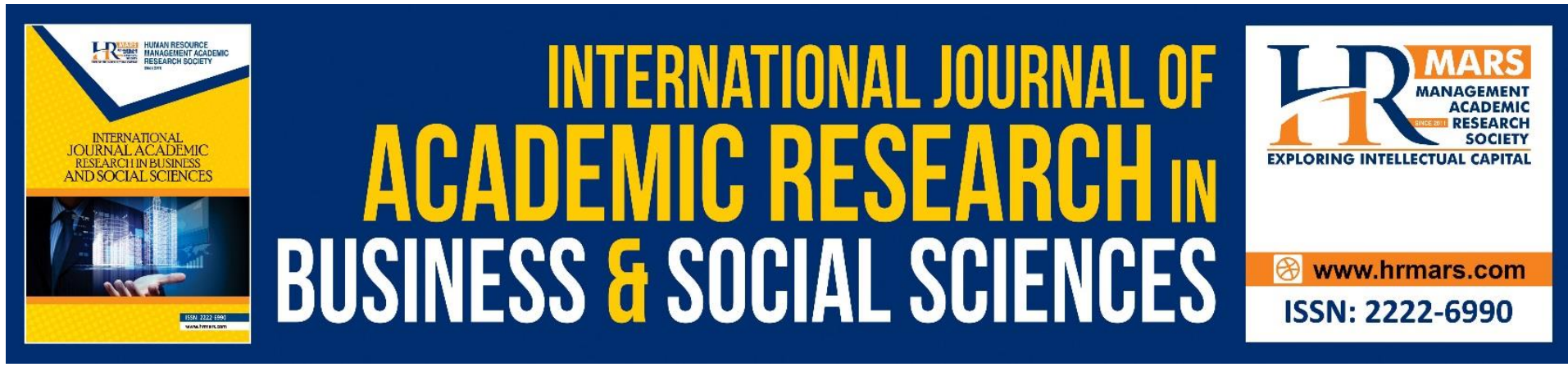

\title{
Language Learning Strategies among Undergraduates During Online Learning in Covid- 19 Pandemic in A Public University in Malaysia
}

\author{
Amizan Azim Ramli, Ashinida Aladdin \\ Centre for Research on Language and Linguistics Faculty of Social Sciences and Humanities \\ Universiti Kebangsaan Malaysi \\ Corresponding Author: ashi@ukm.edu.my
}

\begin{abstract}
One of the most critical aspects of an effective language learner, according to studies, is the adoption of efficient language learning strategies. As the outbreak of the Coronavirus 19 (COVID-19) pandemic has created alterations to the educational sector in which, including the Online Distance Learning (ODL) has become pivotal. On the other hand, suitable language learning strategies should be accessible and accommodating to all learners. Therefore, it is essential to ensure students' English language mastery in any educational environment. This study aimed to identify the most frequent Language Learning Strategies (LLS) utilised by undergraduate learners of English as a second language and to study the factors of specific LLS preferred by the learners during the ODL in the pandemic of Covid-19. This research incorporated a mixed-method design by employing both quantitative and qualitative methods. The research instrument for the quantitative approach is the online questionnaire namely Strategy of Inventory Language Learning (SILL) version 7.0 was adopted and adapted from Oxford (1989). The questionnaire was distributed using a purposive sampling to 78 respondents at a public university in Malaysia namely University Kebangsaan Malaysia (UKM). The second research instrument is semi-structured interviews conducted with 10 participants. Quantitative data was analysed and presented in a descriptive analysis to identify the most frequent LLS used by the participants. Moreover, the qualitative data was scrutinised and coded using thematic analysis. The quantitative results indicated a high preference for social strategies followed by metacognitive, compensation, cognitive, memory, and affective strategies. Thematic analysis for the qualitative method revealed that the social strategies utilised by the students were influenced by achievement goal-oriented, and a learning environment.
\end{abstract}

Keywords: Language Learning Strategies, Covid-19, Online Distance Learning, English As A Second Language, Undergraduates, Malaysia

\section{Introduction}

Problem Statement

Face-to-face interaction accounts for the vast majority of a student's formal learning. Due to Covid-19 pandemic, the closure of learning institutions and the transfer to the online distance 
learning (ODL) could affect their learning performance. In April 2020, the Malaysian government decreed that students return to their hometown and carry out their studies online. By offering an internet incentive to the B40 family and students to access the internet and complete their ongoing online evaluation, the Malaysian government has played an important role in providing supplemental help.

According to some previous studies, physical tertiary education institutions and the implementation of online distance learning may negatively affect students' learning through four main features: spending less time learning, stress symptoms, alterations in how students interact, and an absence of learning motivation. (Azlan et al., 2020; Martin \& Bolliger, 2018; Nasir et al., 2020; Zhu et al., 2020). Despite this, remote education is crucial for ensuring learning continuity and longevity when in-person lessons are no longer possible. According to a study conducted in Malaysia, students' digital literacy and personal demographic factors such as gender, ethnicity, course year level, and financial compensation status impact their online learning reliability (Lau, 2012).

In the context of this study, to be more innovative and practical towards the current educational method, it becomes more vital to identify some LLS employed by the students learning English as second language (Ahmadi, 2018). In these emergency statuses, what is essential is placing the preferred LLS and students' compensation. Additionally, the reasons of undergraduate students for choosing the specific LLS during ODL in the pandemic situation have not yet been fully justified by the past researchers. What is missing is the thematic aspects of the student's reasons. However, some studies dealt with understanding the students' preferences (Hashim et al., 2018; Muniandy, 2016; Sahragard et al., 2016). The argument on the lack of research was stated in the studies conducted before the COVID-19 pandemic by several authors (Hidayah, 2020; Karuppannan \& Mohammed, 2020). A more comprehensive research prospect is needed to address the factors of the students preferred a specific LLS as the online distance learners. Therefore, using the adopted and adapted Strategies Inventory of Language Learning (SILL) by Oxford (1989), it could disclose some of the preferred language learning strategies by 78 respondents of English as second language learners Thus, the main objectives of this study are:

1. To identify the most frequent Language Learning Strategies utilised by the undergraduate learners of English as a second language during Online Distance Learning (ODL) in the pandemic.

2. To study the factors of specific Language Learning Strategies preferred by the learners during Online Distance Learning in the pandemic.

\section{Literature Review}

\section{Language Learning Strategies}

One of the foremost researchers studying language learning strategies, Rubin (1975), defines language strategies as the learners' practices to master a specific language. After many years of examining the tactics of successful learners, Rubin (1975, p. 49) branded two types of learning strategies: strategies that "directly affect learning (clarification/verification, guessing/inductive inference, deductive reasoning, practice, memorization, monitoring)" and ones that "contribute indirectly to the learning (planning, prioritizing, setting goals, selfmanagement)". Rubin (1975) proposed some techniques for the subcategories under the direct strategies; Clarification/Verification, Monitoring strategy, Memorization Strategy, Guessing/Inductive Reference, Deductive Reasoning, and Practice. 
A more ubiquitous framework is introduced by Oxford (1990). She divided all six strategy categories into two primary groups; Direct Strategies and Indirect Strategies. Direct strategies are the language learning strategies that directly incorporate the target language. All of the direct strategies prerequisite mental processing of the language. In the direct strategies category, there are three groups; a) cognitive strategies b) memory strategies c) compensation strategies. Cognitive strategies are one learning strategy that learners use to learn more successfully. These include repetition, organising a new language, summarising meaning, guessing meaning from context, using imagery for memorisation. In addition, the habitual function of tweaking or transforming the target languages is part of the mental capacities to trigger the learners to comprehend and yield new language in many different situations. There are four cognitive strategies; practicing, receiving and sending messages, analysing and reasoning, and creating input and output structure. Furthermore, memory strategies is the arrangement of principles, such as organising things in order or making associations. These associations must be personally meaningful to the learner. Memory strategies allow learners to store vocabulary and then retrieve them when needed for communication. The memory strategies accommodate students to store and retrieve new information. Moreover, compensation strategies are communication strategies used by learners to compensate for limitations in their language. Compensation approaches enable learners to employ the language despite their constraints in knowledge. The purpose of utilising compensation strategies is to provide the ability to predict or counterbalance the lack of understanding with the use of synonyms or gestures in speech.

Indirect strategies provide additional support and manage the language learning process without directly involving the target language. There are three groups of indirect strategies; a) metacognitive, b) affective strategies, c) social strategies. The metacognitive strategies allow the learners to regulate their cognition to make coordination to better comprehend and progress their cognitive abilities. Metacognitive strategies later comprise three units; centering learning, arranging and planning for education, and assessing learning. Metacognitive strategies empower people to control their own knowledge. It entails recognizing how they learn, evaluating their learning requirements, devising strategies to satisfy those needs, and finally putting the plan into action. Kashefian-Naeeini \& Maarof (2010) disclosed that the abilities are typically acquired at a later stage of development. Metacognitive methods are frequently (but not always) mentioned by the person who employs them. Next, affective strategies help control emotions, motivations, and values that strongly impact learners and language learning, such as reducing anxiety, encouraging, and assessing emotional temperature. According to Brown (2016), the affective region is impossible to describe within grasp. It involves many concepts like; self-esteem, attitudes, motivation, anxiety, cultural shock, inhibition, risk-taking, and tolerance for ambiguity. Language learners who control their moods and emotions about learning are more likely to succeed. Furthermore, the sensations of relaxation and happiness would increase learners' motivation to study the language. According to the findings of a previous study, motivation and satisfaction are one of the predictors of a learner's accomplishment (Carreira, 2011). Additionally, since language is a form of social behavior because it is used for communication between and among people, social strategies function a mode of interaction for learners to attain more effective language understanding and obtain a better interpretation of different cultures. The social strategies provide the students to determine through interaction with others. People's feelings, attitudes, anxieties, and motivations impact language learning and 
performance. Most importantly, language learners need to interact with proficient English speakers to progress (Fadda, 2019; Lasfeto \& Ulfa, 2020; Oga-Baldwin et al., 2017).

There is a lot of study in LLS about distinct talents or different aspects of their classroom application. Chamot \& O' Malley (1990) conducted a two-phased study on the utilization of English language learning procedures as a second language. A total of $70 \mathrm{ESL}$ learner and 22 ESL teachers took part in the study. The students were interviewed in their original language for their approaches, and a list was created based on their responses. Metacognitive, cognitive, and social methods are among the most commonly used by second language learners. At the same time, another researchers discovered that memory, cognitive, social, and affective skills were employed frequently by 116 and 174 Thai and Vietnamese students majoring in English (Tieocharoen \& Rimkeeratikul, 2019).

Findings from a study conducted by Zakaria et al. (2018) at a local Malaysian school with the participation of 60 kids. The study's findings revealed that the participants' compensation technique was the most commonly used strategy. Nevertheless, a different result from a survey administered by Aziz \& Shah (2020) was discovered among the 107 Polytechnic engineering majors in Sarawak. The students preferred to use social learning strategies the most as compared to other learning strategies. The metacognitive strategy was their most preferred learning strategies followed by cognitive approaches, compensation, affective, and social strategy being the least. This is dissimilar from other studies involving university students in Malaysia (Nayan \& Krishnasamy, 2019; Nordin et al., 2019). One possible reason could be due to their program of study, which is engineering. Thus, it shows that there is a possibility that students of engineering technology might produce a different result than students from other fields of study.

\section{Past Research on Online Distance Learning Strategies}

The use of learning strategies and the issue of the students' language learning strategies are relatively well-covered. Furthermore, there is abundant research on language learning strategies in distance learning students. On this subject, some noteworthy study has already been completed. Filcher \& Miller (2000) conducted one of the research studies at lowa State University College. As a consequence of the survey, students are looking for a calm, serene location to learn where they will not be bothered. Furthermore, the study discovered that the practicality of self-directed learning is closely linked to the student's mood, self-confidence, self-belief, tenacity, and several character attributes. R. E. Brown (2001) also claims that the student's traits, autonomy, experience, and intrinsic drive influence their learning in a distance learning environment. The students' efficiency of remote learning is connected chiefly with external and internal motivation (Fadda, 2019; Hassan \& Hashim, 2021; KukulskaHulme \& Viberg, 2018; Khalid et al., 2020; Sutarto et al., 2020). Graham \& Oxford (1993) ran a research questionnaire and found that motivation is the most essential component in determining the efficacy of remote learning scenarios. Pelikan et al. (2021) obtained similar concerns with the motivations from their study. According to the findings, more motivated students employ a more comprehensive learning and metacognitive strategies. According to Filcher \& Miller (2000), students in the e-learning ecosystem strongly desire to use effective learning practices. For example, students go deeper into the learning process by drawing their study activities, monitoring, and evaluating their learning outcomes. 
Therefore, the studies mentioned have depicted that if students have a defective learning motivation, they cannot portray the expected results in their learning. According to Brown (2016), the student's motivation level is concerned with their involvement in educational activities, interaction within the online environment, feedback qualities, and learning competencies. Filcher \& Miller (2000) discovered that the interaction with other classmates and instructors was vital for the students. Their research showed that most distance learners maintain communication with their classmates. Only $18.9 \%$ of the students studied merely in the source of tutorials. Together they support, motivate and help each other. Motiwalla \& Tello (2000) also observed that collaboration is one of the most active stimulants for distance learners. Instruments that sustain the cooperation include document sharing and editing, discussion forums, online meetings, and virtual classroom. Online interaction also aids in increasing student motivation and guiding the switch of information within the virtual environment.

Seven hundred fifty-eight distance learners have participated in research conducted by Waddington (2019). The studies displayed the correspondence between learning effectiveness and a proper learning strategy, precisely the metacognitive approach, to help the study succeed. Following the Australian longitudinal study survey by Karuppannan \& Mohammed (2020), the earlier mentioned learning strategies are fundamental for distance learners. Before acquiring the information from the study materials, the students handle a primary reading method to scan the text, followed by an in-depth review to memorize as much input as possible from the text material. Students approach the text critically and interactively during the initial phase, visually the vital elements, write notes, and categorize the information to help them navigate the text. Students also tend to rephrase the read text in their own understanding to be an effective learning strategy.

A copiousness of studies has studied the online language learning strategies by focusing on the variation of variables, aspects, and contexts with the relevant and notable findings that have been conducted locally during the pandemic (Azmuddin et al., 2020; Hasram et al., 2020; Mazlan et al., 2021; Nasri \& Mydin, 2017; Soh et al., 2018). These previous studies were disclosing that online learning strategies were the center of concern since the pandemic. The inquiries on online learning strategies have captured the interest of researchers to distinguish the significance and relationship between the learners and multiple variables such as environment, objectives, and satisfaction. Most of these variables have been reviewed by researchers to recognize whether the variables will affect the inclination and frequency use of language learning strategies among language learners.

\section{Method}

The study engaged a mixed-methods approach that included quantitative and qualitative data collection methods and to triangulate the data gathered. Following this, Creswell \& Poth (2018) explains that research involving collecting, analysing, and integrating quantitative and qualitative methods provides the more exceptional result of the whole study and a better understanding of the research problem than either of each alone.

\section{Respondents of the Study}

The participants were undergraduate learners of English as a second language in UKM. The number of respondents taking part in the survey is 78 participants. While ten percent of the 
actual number of respondents, 10 students were selected for the semi-structured interview. A total of 52 female students and 26 male students were primarily young adults, and their ages vary from 18 to 22 years old. The sampling method followed a purposive sampling method where all the 78 respondents enrolled in English as second language course. The Google survey form was sent to respondents through e-mails and also via WhatsApp.

\section{Research Instruments}

Two research instruments were employed to collect quantitative and qualitative data. First, the questionnaire exploring the students' general language learning strategies during ODL was adopted and adapted from the Strategy Inventory for Language Learning (SILL) version 7.0 developed by Oxford in 1989. It has been primarily used to explore general factors contributing significantly to academic and language learning in higher education; its validity and reliability have been acknowledged worldwide. The questionnaire consists of 50 statement items representing five learning strategies: memory, cognitive, compensation, metacognitive, affective, and social. The frequency of strategy use was measured through 4point Likert scales. However, the researcher adopted and adapted the SILL questionnaire and transformed it into a more versatile manner via Google Form. Thirdly, semi-structured interviews add a qualitative dimension to the study, complement the questionnaires' quantitative findings, probe, and expand in detail (Creswell \& Creswell, 2018). The interviews were used to explore more insights into the respondents' justifications of using the most frequent learning strategies during online distance learning in the COVID-19 pandemic era. The online questionnaire has undergone reliability and validity process for each item of the constructs and the result exhibited a satisfactory alpha value of 0.812 . According to Kline (2015), the coefficient of alpha value that exceeding 0.7 is a good and reliable alpha value. The pilot study of the online survey has been conducted and amendment has been made to the actual questionnaire accordingly.

\section{Research Procedure}

The data were collected from 78 respondents, who participated in the SILL questionnaires through online surveys. This method was chosen for some reasons, such as being developed in less time compared to other data collection methods. In addition, it can collect data from an abundance of respondents, allowing numerous questions asked about a subject, extensive data analysis flexibility, and, finally, being cost-effective. The interview procedure, however, was carried out through WhatsApp. Therefore, only 10 students will be picked and interviewed. Thus, the interview question is a semi-structured procedure.

\section{Data Analysis}

The quantitative data from the online survey of the adapted and adopted Strategy Inventory for Language Learning SILL version 7.0 by Oxford (1989) collected from 78 respondents were analysed using statistical software, SPSS (version 20). SPSS was selected because of its compatibility with most other software packages that can handle substantial data and the user-friendliness used for data analysis. Data were analysed by using descriptive statistics. Frequency, mean and standard deviation were drawn, and the data was presented in the form of tables.

The qualitative analysis of the interview data was carried out to answer the second research question. The interview was administered with the ten selected students from the survey questionnaire. Ten selected students denoted their point of view in a semi-structured 
interview based on the questions asked by the researcher. It was imminent for the researcher to go through the transcription numerous times to decipher the interview data. According to Hashim et al. (2018), it is vital to analyse the data correctly. The researcher will later concentrate on the relevant thematic analyses that adhere to the second research question. All the responses were focused on the six categories of language learning strategies. Thematic analysis is an exploratory technique where the researcher codes and characterises a particular text's sections based on the patterns that constitute some appropriate themes (Flick, 2018).

\section{Findings and Discussion}

This section displays the quantitative data collected from 78 participants and the qualitative data acquired from the semi-structured interviews with 10 participants. The results in this study aim to satisfy the research objectives. The purposes of this part are listed as follows; 1 ) To identify the most frequent Language Learning Strategies for ESL undergraduates during ODL in the pandemic of Covid-19 and 2) To study the factors of specific Language Learning Strategies preferred by the ESL undergraduates during ODL in the pandemic of Covid-19.

\section{Demographics Background}

In the first section of the questionnaire, the respondents of 78 ESL participants were prompted to indicate their gender, age, race, MUET band level, Internet performance, and learning premises to discover the demographic information. All of this information was required due to the participant's current dynamic environment. The background information receive could later aggregate the variables of the study.

TABLE 1. Demographics of the respondents

\begin{tabular}{llll}
\hline Variable & Type & Numbers & Percentage (\%) \\
\hline \multirow{2}{*}{ Gender } & Male & 27 & 34.6 \\
\multirow{2}{*}{ Age } & Female & 51 & 65.4 \\
& $20-22$ & 41 & 52.6 \\
\multirow{2}{*}{ Race } & $23-25$ & 37 & 47.4 \\
& Malay & 66 & 84.6 \\
& Indian & 5 & 6.4 \\
Internet Connectivity & Chinese & 3 & 3.8 \\
& Others & 4 & 5.1 \\
Learning Premise & Hoor & 72 & 92.3 \\
& University & 6 & 7.7 \\
MUET Band & Band 4 & 62 & 79.5 \\
& Band 5 & 69 & 20.5 \\
\hline
\end{tabular}


Table 1 shows the demographic background of the respondents. Among the respondents $(n=78)$ involved in the study, $65.4 \%(n=51)$ of them were female, whereas $34.6(n=27)$ of them were male. More than half $n=41$ (52.6\%) of the respondents who had answered the questionnaire were between 20 and 22 years old and followed by $n=37$ (47.4) of the age group between 23-25. The participants were from various races, namely Malay, Indian, Chinese, and others, representing the ethnic diversities of Malaysia. Malay was the most extensive group of the sample (84.6\%), followed by Indians (6.4\%). The third-largest race group was other ethnic groups such as Iban, Bidayuh, and Bugis (5.1\%) and Chinese comprised $3.8 \%$ of the sample. The majority $n=72(92.3 \%)$ of the respondents rated their internet performance on a good level acknowledging whether they are staying at home or the university and only $n=6$ (7.7\%) have a poor internet connectivity. Regarding the students' learning premise, there were 62 of them, which account for the $79.5 \%$ of the respondents staying at home while the remaining 16 of them were continuing to be at the university and it took up $20.5 \%$ of the total number of participants. In this study, most of the respondents primarily obtained Band 4 (88\%) in the Malaysian University English Test (MUET). The remaining respondents, $n=9$ $(11.6 \%)$, received Band 5, which is the highest band of MUET.

\section{Findings on the Most Frequent Language Learning Strategies}

Returning to the first research objective, a descriptive statistic was applied to the data cohort encompassing the mean scores of the SILL items. The participants of this study were the undergraduate learners of English as a second language in UKM. From the demographic findings, 27 males and 51 female students responded to the questionnaire based on the six language learning strategies identified by Oxford (1990). As mentioned previously, the questionnaire was adapted from Oxford (1989) and employs a 4-point Likert scale. Therefore, the value of the assigned response varied from 1 to 4 (Strongly Disagree to Strongly Agree). In addition, 50 items were distributed into six categories of strategies, namely memory, cognitive, compensation, affective, and social. The quantitative data were presented in a descriptive analysis. 
TABLE 2. Descriptive Analysis for the SILL

\begin{tabular}{|c|c|c|c|c|c|c|}
\hline Item & $\begin{array}{l}\text { Strongly } \\
\text { Disagree } \\
\mathrm{f} \\
(\%)\end{array}$ & $\begin{array}{l}\text { Disagree } \\
\mathrm{f} \\
(\%)\end{array}$ & $\begin{array}{l}\text { Agree } \\
\text { f } \\
(\%)\end{array}$ & $\begin{array}{l}\text { Strongly } \\
\text { agree } \\
\mathrm{f} \\
(\%)\end{array}$ & $\begin{array}{l}\text { Mean } \\
\mathrm{f} \\
(\%)\end{array}$ & $\begin{array}{l}\text { Standard } \\
\text { Deviatio } \\
\mathbf{n} \\
\mathrm{f} \\
(\%)\end{array}$ \\
\hline $\begin{array}{l}\text { Memory } \\
\text { Strategies }\end{array}$ & $\begin{array}{l}17 \\
(21.8)\end{array}$ & $\begin{array}{l}39 \\
(50.0)\end{array}$ & $\begin{array}{l}14 \\
(17.9)\end{array}$ & $\begin{array}{l}9 \\
(10.3)\end{array}$ & 2.166 & .888 \\
\hline $\begin{array}{l}\text { Cognitive } \\
\text { Strategies }\end{array}$ & $\begin{array}{l}9 \\
(11.5)\end{array}$ & $\begin{array}{l}39 \\
(50.0)\end{array}$ & $\begin{array}{l}22 \\
(28.2)\end{array}$ & $\begin{array}{l}8 \\
(10.3)\end{array}$ & 2.371 & .823 \\
\hline $\begin{array}{l}\text { Compensatio } \\
\mathrm{n} \\
\text { Strategies }\end{array}$ & $\begin{array}{l}8 \\
(10.3)\end{array}$ & $\begin{array}{l}37 \\
(47.4)\end{array}$ & $\begin{array}{l}20 \\
(25.6)\end{array}$ & $\begin{array}{l}13 \\
(16.7)\end{array}$ & 2.487 & .893 \\
\hline $\begin{array}{l}\text { Metacognitiv } \\
\text { e Strategies }\end{array}$ & $\begin{array}{l}5 \\
(6.4)\end{array}$ & $\begin{array}{l}24 \\
(30.8)\end{array}$ & $\begin{array}{l}34 \\
(43.6)\end{array}$ & $\begin{array}{l}15 \\
(19.2)\end{array}$ & 2.756 & .840 \\
\hline $\begin{array}{l}\text { Affective } \\
\text { Strategies }\end{array}$ & $\begin{array}{l}21 \\
(26.9)\end{array}$ & $\begin{array}{l}33 \\
(42.3)\end{array}$ & $\begin{array}{l}14 \\
(17.9)\end{array}$ & $\begin{array}{l}10 \\
(12.8)\end{array}$ & 2.166 & .972 \\
\hline $\begin{array}{l}\text { Social } \\
\text { Strategies }\end{array}$ & $\begin{array}{l}4 \\
(5.1)\end{array}$ & $\begin{array}{l}19 \\
(24.4)\end{array}$ & $\begin{array}{l}39 \\
(50.0)\end{array}$ & $\begin{array}{l}16 \\
(20.5)\end{array}$ & 2.859 & .801 \\
\hline
\end{tabular}

The analysis of the SILL questionnaire is the scheme to distinguish the most prevalent language learning strategies among the participants as shown in Table 2. Therefore, the categorisation of 50 items into six strategy groups was scrutinised thoroughly. Correspondingly, the details obtained from the descriptive analysis, which incorporate the mean and standard deviation values, were enumerated in a table form above. Table 2 illustrated the mean value of $2.166(S D=.888)$ for the memory strategies, the mean value of $2.371(\mathrm{SD}=.823)$ for the cognitive processes, the mean value of 2.487 ( $S D=.893)$ for the compensation strategies, the mean score of $2.756(\mathrm{SD}=.840)$ for the metacognitive strategies, the mean value of $2.166(S D=.972)$ for affective systems and lastly 2.859 mean the social processes acquired significance $(S D=.801)$. Henceforth, it was considerably distinct that the respondents had a notable high preference for using social strategies as it had the highest mean value followed by metacognitive strategies. The remaining four types of strategies were assigned in the medium-use range. Besides, the frequency and the percentage values as stated in the table above played a significant role in indicating the level of agreement over the preferred language learning strategies by the participants.

As mentioned earlier, the first objective of the study is to identify the most frequent language learning strategies used during online distance learning as shown in Table 2. The descriptive analysis result corresponds with a previous study identifying Malaysian public university undergraduate students' language learning strategies preferences (Shah et al., 2013). Their research also reported that the students' social strategies serve as the most preferred. The present study indicated that the indirect approach allows the major learning 
strategies while the straightforward procedures are minor. Another study also came out with the same result; social strategies and metacognitive strategies as the students' preferences (Lestari \& Wahyudin, 2020).

Social strategies ranked the highest among the learning strategies, followed by the metacognitive strategies. In contrast, the affective strategies are ranked the lowest. It signifies that most students have the tendencies to learn through socialising with peers and instructors during online learning. One of the past studies regarding online learning strategies also indicated that social influence has significantly affected the students' behavioral performance during online learning (Yunus et al., 2021). The speculation for students to have the least favourable preferences toward affective strategies is the cause of negative emotion experienced by the students during the Covid-19 pandemic lockdown (Wang et al., 2020). Since affective strategies are more on preserving individual mental stability, there are chances that the condition and the learning environment are defecting the learner's ability to stay sane during the lockdown period.

The second most frequent used of language learning strategies in this study is metacognitive strategies $(M=2.756)$. The results have highlighted the learners as innerdirected learners in their language learning process. Customarily, they think planning and help-seeking towards attaining a better learning process during online learning settings (Lin, 2021). These undergraduates' learners of English as a second language know their objectives to improve their learning process and achieve better results. The majority of them have discerned how to be better learners during online learning sessions. Oxford (1990) explains metacognitive strategies as a group of proficient strategies. These strategies will guide the learners to make arrangements, plan, and judge their learning manner to ensure that they are always conscious about their learning process. Going deeper into the ESL undergraduates preferred language learning strategies, based on the findings, metacognitive strategies permit the learners to monitor their improvement when they experience and learn something. Some prefer to intensify their English language by learning from making mistakes. It can be assumed that the learner's self-regulation in ascertaining their development during a virtual learning environment (Gaeta et al., 2021).

The employment of affective approaches was also the less frequent used strategy (Javed \& Ali, 2018; Nayan et al., 2019; Saud, 2019). Most of the tertiary level learners were discerned the least utilisation of affective strategies compared to the other language learning strategies. Emotional factors such as stalemate of passion, distress, or anxiety are the boundaries to online learning (Cho, 2019). Therefore, it is imperative for every student that learns in online settings to manage their emotional stability to have a better learning process especially during a sudden change of educational setting caused by the pandemic Covid-19. For the respondents of this study, it may suggest that most of them have ascertained that they maintain their emotional stability.

\section{Findings on the Factors of the Language Learning Strategies Preferred by the ESL Learners} In order to explore the factors of specific Language Learning Strategies chosen by the ESL undergraduates during ODL in the pandemic COVID-19 era, five interview questions were adapted from Peng (2019) and modified; 1) What are your purposes for utilising preferred language learning strategies? 2) How is your sustainability in learning the language during 
online distance situations when the preferred learning strategies are used?; and Why) 3) Describe what learners you are during the online learning atmosphere when you use your preferred learning strategies; and Why? 4) Do you think your preferred learning strategies will increase your competencies learning the language during an online distance environment?

TABLE 3. The Purpose of Students' Preferences over Language Learning Strategies

\begin{tabular}{|c|c|c|}
\hline $\begin{array}{l}\text { Achievement } \\
\text { Orientation }\end{array}$ & Goal & Purpose \\
\hline Learning goal orientation & & $\begin{array}{l}\text { Achieving a better learning process } \\
\text { Utilize all the skills } \\
\text { Easier to understand } \\
\text { Apply in real life situation }\end{array}$ \\
\hline $\begin{array}{l}\text { Performance } \\
\text { orientation }\end{array}$ & goal & Insecurity to talk in public \\
\hline
\end{tabular}

Table 3 shows the identified theme from the response of question one. After carefully examining the interview transcription for question two, open coding was administered to dissect the concepts and categories. Consequently, some sub-themes from the central achievement goal-oriented theme were identified in this question responses, including learning goal orientation and performance goal orientation. The majority of the students $(n=10)$ were mindful of the necessity of setting up learning objectives. Among ten participants involved in the interview session, some intend to utilise learning strategies as a beneficial tool to help them learn more effectively (Respondent $1,2,3,6,8,10$ ). The first orientation usually to improve their learning process, including easier to identify important points, make use of their English skills, and acquire knowledge, as one respondent claimed; "I would like to say that this kind of strategy helps store and retrieve information related to language" (Respondent 1). In contrast, only the minority of them (Respondent 4 and 9) tried to compensate their learning abilities by stating, "I am using it because as an introverted person, I am actually shy to speak or take part in English long conversation like how social strategy would be like." Since respondent 4 is less likely to interact during online classes, there is a logical assumption that it may be the factor of the respondent using that particular language learning strategies.

TABLE 4. The Students' Learning Environment During Online Learning

\begin{tabular}{ll}
\hline Learning Environment & Response \\
\hline & Practice atmosphere \\
A place to increase their competence & Freedom of learning method \\
Interact with peers to increase understanding \\
Less constraints to use multiple strategies \\
Change to other strategies \\
Challenges & Need peers to increase competence \\
& Difficult learning situation \\
& Traditional learning is better \\
\hline
\end{tabular}


Table 4 refers to the themes that have been identified based on question no.4. Besides accentuating the students' attitude on their specific aim to employ the preferred language learning strategies, the respondents share their everyday experiences as they learn the English language through an online learning atmosphere. Therefore, the theme of the learning environment was able to be extracted from question four. The learning environment has a broad scope. It can be associated with opportunities that encompass good learning facilities, teaching building, learning atmosphere, and lecturer-student relationships. About $50 \%$ of them were ascertained that they were determined to discredit the fact that they could take the benefit from the preferred learning strategies by making them to become more competent during online learning environment (Respondent 1, 2, 8, 9, 10) "Yes. I think my approach in learning can be used in both settings. But, I can say online classes will give you the chance to fully utilize the strategy. So, in a simple note, yes. This approach will increase competence in language learning during an ODL. Simply because learning language takes a lot of focus and practice where u can equip this approach to allow language learning to be easy and fun".

The remaining respondents who have alleged that learning in an online distance environment were perceived as challenges (Respondent 3, 4, 5, 6, 7) "To be honest, it's quite difficult for me to learn at the current situation. The reason why I think it's difficult for me maybe because of the environment itself. I don't think I'm in a good learning environment and I believe that it's important to have a good learning environment. It's because it can help me to improve my intention, and maybe reduce my anxiety." Consequently, these respondents seemed to be determined and confident as having the potent tendency to manage their online learning process with the ultimate goal of improving their language competence. Henceforth, it has been hypothesized that the association between competence and their preferred language learning strategies existed. The respondents' autonomy was crucial to sustaining them further to put their effort in their learning process and adapt during online learning. By examining the response stated by respondent 5 earlier, it was informed of the prevailing difficulties experienced by the respondent. Respondent 4 said that "I need people too to increase my competence because my competence in learning maybe turns out to be static". This social approach prompted them to practice and develop their English competency level to the most maximum level. Another study shed the same light over the importance of socializing with peers during informal online learning by (Rahimah et al., 2014) . Their study has highlighted the communication aspects being one of the most significant result in Web 2.0 tool in online learning strategies. This acts as scaffolding and support as the student can learn in the interactive environment.

In addition, the undergraduates' competencies are due to environmental factors. The online environment was perceived to be the principal of the student's level of learning competency. The appropriate environment settings will promote autonomy and independence in language learning. The Malaysian ESL students widely admitted the online learning environment as an infinite opportunity for language learning (Gaeta et al., 2021). The students could decide the most relevant resources to assist their language learning during online sessions. Prior studies have also authenticated that online learning has provided supplement assistance to students' traditional ESL learning and teaching (Khalid et al., 2020; Wong et al., 2019). It has provided the foundation for them to acquire outside classrooms' 
knowledge to expand their learning exceeding the traditional learning setting into a more independent context.

Online learning has provided the layout to aid in eradicating the boundary and has enabled ESL students in different learning settings to have equal openings for language learning, rather than just students who seem to be in the formal learning settings (Alawamleh et al., 2020). As highlighted in the previous interview thematic analysis results, online ESL learning prompts some students to access extra learning materials, including authentic ones from the lecturers' slides but less physical constraints. The privileges of online learning could meet the ESL students' requirement of learning resources in a more voluminous array and a way to improve learning competencies (Martin et al., 2020).

It was also found that the constant changing of the learning environment was one of the significant challenges faced by the ESL learners. Some of them in the interview sessions have highlighted that they cannot rely on one specific strategy as stated by respondent 5 "Honestly not exactly. I think I have to change to other strategies from time to time to suit different types of courses I'm learning". According to some students, online learning might require further adaptation to particular subject requirements and learning environments or increasing their competencies (Martin \& Bolliger, 2018). The transitions from traditional to online learning environments were prior issues for language learning competencies (Khalid et al., 2020). One of the students in this interview session also disclosed the importance of interaction during online learning to improve their learning competencies. One previous study by Hashim et al., (2014) has also announced this over the teacher's performance and students' communication proficiency in English. The results have found that the teacher's interaction qualities during the traditional learning environment would increase the students' motivation to learn. Furthermore, the digital solitudes may have created barriers for independent learning since language learning might have insufficient facilities for online interaction. From the respondent's perspective, it may suggest that most ESL learners among undergraduates frequently use social strategies. The existing studies have also noticed the importance of socializing during online learning (Lasfeto \& Ulfa, 2020; Khalid et al., 2020; Nayan et al., 2019).

One of the ESL undergraduates interview participants explicitly expressed their dislike of the online learning environment and would still prefers the traditional learning method as there are hands-on evaluations such as presentations; "I still think that, traditional classroom is the best way to learn English language. This is because, during traditional classroom, we have a presentation in front of the class. That will improve us more in terms of speaking and confidence in the language. We also can learn by watching others people during the presentation too." As previous studies have implied, these new teaching and learning norms might negatively impact students' language learning development (Di Pietro et al., 2020; Gaeta et al., 2021; Lovrić et al., 2020). These sudden changes in learning situation might require the students to adjust to the new learning settings as they were considerably dependent on their individual preferences and influenced by traditional learning methods

\section{Conclusion}

The main objective of the research was to highlight the language learning strategies utilised by the undergraduate learners of English as second language in a public university in Malaysia. 
The results have indicated that the two sub-categories of indirect strategies with the highest mean scores were identified as social and metacognitive strategies with the mean scores of 2.859 2.756, respectively. While the other four methods were perceived as the minor language learning strategies with affective strategies scored the lowest mean (2.166). Therefore, studies associated with language learning strategies are meaningful in the focal point of language learning and educational setting. Research on remote learners can bring up various viewpoints and opinions among academics, educators, and practitioners to scrutinise the strategies and their preferred strategies to support them to learn a language in online settings. The current study has to render shrewdness on factors affecting the students to prefer specific language learning strategies in the pandemic. The study also discloses that most students prefer to utilise social strategies when learning remotely. This judgment ties to the perspective in which socialising in online learning will aid them to progress (Shakarami et al., 2017). Hence, language learners require to increase their engagement with their peers and instructors when learning remotely. As a conclusion, through the data and discussions previously, it was found that the ESL undergraduates are actively engaged in online learning during the pandemic by utilising their preferred language learning strategies. Therefore, this study procuring the students' perspectives about their preferred language learning strategies will stimulate the educators and researchers to investigate and comprehend the justifications behind them.

The current study contributes to educators, students, and practitioners in myriad ways. From the result of this study, it can primarily inculcate how it provides comprehensive information about the students' preferred LLS during the pandemic circumstances. Likewise, it discloses the factors including learning strategies and online distance learning. In this way, it will pave the way for future educators in Malaysia about the fundamental aspects of being more concerned about the students' diversities and considering teaching alternatives simultaneously and incorporating them during ODL. Finally, through this study, a comprehensive understanding of the students' LLS profiles will be obtained. As a result, it will benefit the curriculum coordinators and educators in designing practical teaching pedagogical techniques. These eventually will aid the other second or foreign language learners improve their learning process during the pandemic in the most effective ways.

\section{Reference}

Adedoyin, B., \& Soykan, E. (2020). Covid-19 pandemic and online learning: the challenges and opportunities. Interactive Learning Environments, 0(0), 1-13. https://doi.org/10.1080/10494820.2020.1813180

Ahmadi, M. R. (2018). The use of technology in English language learning: A literature review. International Journal of Research in English Education (IJREE) 3(2),115-125.

Alawamleh, M., Al-Twait, L. M., \& Al-Saht, G. R. (2020). The effect of online learning on communication between instructors and students during Covid-19 pandemic. Asian Education and Development Studies. https://doi.org/10.1108/AEDS-06-2020-0131

Aziz, S. N. S. M., \& Shah, P. M. (2020). Language learning strategy (LLS) for English language learners in Polytechnic. Journal of Personalized Learning, 3(1), 71-78.

Azlan, C. A., Wong, J. H. D., Tan, L. K., Shahrun, M. S. N., Ung, N. M., Pallath, V., Tan, C. P. L. (2020). Teaching and learning of postgraduate medical physics using Internet-based elearning during the COVID-19 pandemic-A case study from Malaysia. Physica Medica 80: 10-16. http://dx.doi.org/10.1016/j.ejmp.2020.10.002

Azmuddin, R. A., Nor, M. N. F., \& Hamat, A. (2020). Facilitating online reading comprehension 
in enhanced learning environment using digital annotation tools. IAFOR Journal of Education: Technology in Education, 8(2), 7-27.

Brown, R. E. (2001). The process of community-building in distance learning classes. Journal of Asynchronous Learning Network, 5(2), 18-35. https://doi.org/10.24059/olj.v5i2.1876

Brown, S. (2016). L2 listening. In Handbook of Research in Second Language Teaching and Learning (Vol. 3, pp. 201-213). https://doi.org/10.4324/9781315716893

Carreira, J. M. (2011). Relationship between motivation for learning EFL and intrinsic motivation for learning in general among Japanese elementary school students. In System 39 (1), 90-102. https://doi.org/10.1016/j.system.2011.01.009

O'Malley, J. M., \& Chamot, A. U. (1990). Learning strategies in second language acquisition. Cambridge, UK: Cambridge University Press.

Creswell, J.W. \& Creswell, J. (2018). Research design: qualitative, quantitative, and mixed methods approaches. 4th ed. Thousand Oaks, California: SAGE Publications.

Di Pietro, G., Biagi, F., Costa, P., Karpiński, Z., \& Mazza, J. (2020). The likely impact of COVID19 on education: Reflections based on the existing literature and recent international datasets. Publications Office of the European Union, Luxembourg: EUR 30275 JRC121071. https://doi.org/10.2760/126686

Fadda, H. Al. (2019). The relationship between self-regulations and online learning in an ESL blended learning context. English Language Teaching, 12(6), 87. https://doi.org/10.5539/elt.v12n6p87

Filcher, C., \& Miller, G. (2000). Learning strategies for distance eduation students. Journal of Agricultural Education, 41(1), 60-68. https://doi.org/10.5032/jae.2000.01060

Flick, U. (2018). Qualitative Data Collection. SAGE Publication. https://doi.org/10.1007/9783-319-54672-8_15

Gaeta, M. L., Gaeta, L., \& Rodriguez, M. del S. (2021). The impact of COVID-19 home confinement on Mexican university students: Emotions, coping strategies, and selfregulated learning. Frontiers in Psychology, 12(April), 1-12.

https://doi.org/10.3389/fpsyg.2021.642823

Graham, M. P., \& Oxford, R. L. (1993). Language learning strategies: What every teacher should know. TESOL Quarterly 27 (1). https://doi.org/10.2307/3586958

Hashim, H. U., Yunus, M. M., \& Hashim, H. (2018). Language learning strategies used by adult learners of teaching English as a second language (TESL). TESOL International Journal, 13(4), 39-48.

Hasram, S., Arif, F. K. M., Nasir, M. K. M., Mohamad, M., Daud, M. Y., Rahman, M. J. A., \& Mohammad, W. M. R. W. (2020). Online games for primary school vocabulary teaching and learning: A literature review. Creative Education, 11(11), 2327-2336. https://doi.org/10.4236/ce.2020.1111170

Hidayah, T. (2020). Preference in language learning strategies (LLS) of the students in the English Language Education Department at the University of Muhammadiyah Jember. Journal of English Language Pedagogy 5(1): 64-75.

Hyonsuk Cho, X. Christine. W. \& Tanya. C. (2019). Social-emotional learning of refugee English language learners in early elementary grades: Teachers' perspectives. Journal of Research In Childhood Education, 33(1), 40-55.

Ida Rahimah, C. W., Prain, V., \& Collet, P. (2014). Perceived learning strategies of Malaysian university students in Web 2.0-based English as a second language informal learning. GEMA Online Journal of Language Studies, 14(1), 29-42.

https://doi.org/10.17576/gema-2014-1401-03 
Javed, M., \& Ali, A. (2018). Analyzing the use of language learning strategies among high and low achievers. Journal of Research and Reflections in Education, 12(1), 25-44.

Karuppannan, S., \& Mohammed, L. A. (2020). Predictive Factors Associated with Online Learning during Covid-19 Pandemic in Malaysia: A conceptual Framework. International Journal of Management and Human Science (IJMHS), 4(4), 19-29. https://ejournal.lucp.net/index.php/ijmhs/article/view/1236

Kashefian-Naeeini, S., \& Maarof, N. (2010). Language learning strategies used by ESL university students. International Journal of Learning, 17(8), 47-62. https://doi.org/10.18848/1447-9494/cgp/v17i08/47224

Kline, P. (2015). A Handbook of Test Construction. Routledge.

Kukulska-Hulme, A., \& Viberg, O. (2018). Mobile collaborative language learning: State of the art. British Journal of Educational Technology, 49(2), 207-218. https://doi.org/10.1111/bjet.12580

Lasfeto, D. B., \& Ulfa, S. (2020). The relationship between self-directed learning and students' social interaction in the online learning environment. Journal of E-Learning and Knowledge Society, 16(2), 34-41. https://doi.org/10.20368/1971-8829/1135078

Lestari, M., \& Wahyudin, A. Y. (2020). Language learning strategies of undergraduate EFL students. Journal of English Language Teaching and Learning, 1(1), 25-30. https://doi.org/10.33365/jeltl.v1i1.242

Lau. (2012). The impacts of personal qualities on online learning readiness at Curtin Sarawak Malaysia (CSM). Educational Research and Reviews 7(20), 430-444. doi:10.5897/err09.229

Lin, T. J. (2021). Exploring the differences in Taiwanese university students' online learning task value, goal orientation, and self-efficacy before and after the COVID-19 outbreak. Asia-Pacific Education Researcher, 30(3), 191-203. https://doi.org/10.1007/s40299-021-00553-1

Martin, F., \& Bolliger, D. U. (2018). Engagement matters: Student perceptions on the importance of engagement strategies in the online learning environment. Online Learning Journal, 22(1), 205-222. https://doi.org/10.24059/olj.v22i1.1092

Martin, F., Stamper, B., \& Flowers, C. (2020). Examining student perception of readiness for online learning: Importance and confidence. Online Learning Journal, 24(2), 38-58. https://doi.org/10.24059/olj.v24i2.2053

Mazlan, A. F., Mohamad, M., Reesha, A., Kassim, R., Othman, Z., \& Kummin, S. (2021). Challenges and strategies to enhance online remote teaching and learning by tertiary institution educators: A literature review. Creative Education, 12(04), 718-726. https://doi.org/10.4236/ce.2021.124050

Nasri, M. N., \& Mydin, F. (2017a). University students' view of self-directed learning in an online learning context. Advances in Social Sciences Research Journal, 4(24), 95-102. https://doi.org/10.6007/IJARPED/v10-i2/9630

Motiwalla, L., \& Tello, S. (2000). Distance learning on the internet: An exploratory study. Internet and Higher Education, 2(1), 253-264. https://doi.org/10.1016/s10967516(00)00026-9

Muniandy, J. (2016). Learning styles, language learning strategies and fields of study among ESL learners. Malaysian Journal of ELT Research 12(1): 1-19.

Nayan, S., \& Krishnasamy, H. N. (2019). Low Achievers and Vocabulary Learning Strategies. Jurnal Intelek, 14(2). 
Nayan, S., Krishnasamy, H. N., Dunn, A. M., Hofmann, O. S., Waters, B., Witchel, E., Zakaria, N. Y. K., Azmi, N. E., Abd Hadi, N. A., Brunca, S., Rica, C., Brunca, S., Rica, C., Language, E., Strategies, L., Average, B., Learners, P., Level, U., Yu, B., Salleh, M. J. (2019). Language learning strategies used by ESL university students. Procedia - Social and Behavioral Sciences, 2(2), 311. https://doi.org/10.17507/jltr.1002.13

Hashim, N. M. H., Alam, S. S., \& Yusoff, N. M. (2014). Relationship between teacher's personality, monitoring, learning environment, and students' EFL performance. GEMA Online Journal of Language Studies, 14(1), 101-116. https://doi.org/10.17576/GEMA2014-1401-07

Nordin, L., Abdul Razak, N. Z., \& Kassim, R. (2019). Language learning strategies from the perspective of undergraduates in a private engineering technology university in Johor. Education, Sustainability \& Society, 2(2), 09-16.

https://doi.org/10.26480/ess.02.2019.09.16

Oga-Baldwin, W. L. Q., Nakata, Y., Parker, P., \& Ryan, R. M. (2017). Motivating young language learners: A longitudinal model of self-determined motivation in elementary school foreign language classes. Contemporary Educational Psychology, 49, 140-150. https://doi.org/10.1016/j.cedpsych.2017.01.010

Oxford, R. L. (1989). Use of language learning strategies: A synthesis of studies with implications for strategy training. System 17(2): 235-247. doi:10.1016/0346251X(89)90036-5

Oxford, R. L. (1990). Language Learning Strategies: What Every Teacher Should Know. Heinle \& Heinle Publishers.

Pelikan, E. R., Lüftenegger, M., Holzer, J., Korlat, S., Spiel, C., \& Schober, B. (2021). Learning during COVID-19: the role of self-regulated learning, motivation, and procrastination for perceived competence. Zeitschrift Fur Erziehungswissenschaft, 24(2), 393-418. https://doi.org/10.1007/s11618-021-01002-x

Peng, H. J. (2019). Correlation Between Learning Style and Language Learning Strategy and Motivation in ESL Classroom. Final Year Project, Universiti Tunku Abdul Rahman.

Rubin, J. (1975). What the good (digital) language learner can teach us? Teaching English with Technology, 16(3), 52-73.

Sahragard, R., Khajavi, Y., \& Abbasian, R. (2016). Field of study, learning styles, and language learning strategies of university students: are there any relations? Innovation in Language Learning and Teaching 10(3): 255-271. doi:10.1080/17501229.2014.976225

Saud, W. I. (2019). A contrastive analysis of ESL and EFL learning strategies. Journal of Language Teaching and Research, 10(2), 311. https://doi.org/10.17507/jltr.1002.13

Shah, M. I. A., Ismail, Y., Mohamed, A. J., \& Esa, Z. (2013). Language learning strategies of English for specific purposes students at a public university in Malaysia. English Language Teaching, 6(1), 153-161. https://doi.org/10.5539/elt.v6n1p153

Shakarami, A., Hajhashemi, K., \& Caltabiano, N. J. (2017). Compensation still matters: Language learning strategies in third millennium ESL learners. Online Learning Journal, 21(3), 235-250. https://doi.org/10.24059/olj.v21i3.1055

Soh, O.K., Lim, L.-A. D., Yee, L. Y., Ying, L. K., \& Yin, L. L. (2018). A review on the students' perceptions of online learning tools in improving English writing skills. International Journal of Academic Research in Progressive Education and Development, 7(4), 324-348. https://doi.org/10.6007/ijarped/v7-i4/4979

Sutarto, S., Sari, D. P., \& Fathurrochman, I. (2020). Teacher strategies in online learning to increase students' interest in learning during COVID-19 pandemic. Jurnal Konseling Dan 
Pendidikan, 8(3), 129. https://doi.org/10.29210/147800

Tieocharoen, W., \& Rimkeeratikul, S. (2019). Learning Strategies and Teaching Methods in Thai and Vietnamese Universities. Arab World English Journal, 10(3), 99-112. https://doi.org/10.24093/awej/vol10no3.7

Waddington, J. (2019). Developing primary school students' foreign language learner selfconcept. System, 82, 39-49. https://doi.org/10.1016/j.system.2019.02.012

Wang, C., Pan, R., Wan, X., Tan, Y., Xu, L., Ho, C. S., \& Ho, R. C. (2020). Immediate psychological responses and associated factors during the initial stage of the 2019 Coronavirus Disease (COVID-19) epidemic among the general population in China. International Journal of Environmental Research and Public Health, 1729(17), 1-25.

https://doi.org/10.1093/qjmed/hcaa110

Wong, J., Baars, M., Davis, D., Van Der Zee, T., Houben, G. J., \& Paas, F. (2019). Supporting self-regulated learning in online learning environments and MOOCs: A systematic review. International Journal of Human-Computer Interaction, 35(4-5), 356-373. https://doi.org/10.1080/10447318.2018.1543084

Yunus, M. M., Ang, W. S., \& Hashim, H. (2021). Factors affecting teaching English as a second language (TESL) postgraduate students' behavioural intention for online learning during the COVID-19 pandemic. Sustainability (Switzerland), 13(6). https://doi.org/10.3390/su13063524

Zakaria, N. Y. K., Zakaria, S. N., \& Azmi, N. E. (2018). Language Learning Strategies Used by Secondary Schools Students in Enhancing Speaking Skills. Creative Education, 09(14), 2357-2366. https://doi.org/10.4236/ce.2018.914176

Zhu, M., Bonk, C. J., \& Doo, M. Y. (2020). Self-directed learning in MOOCs: exploring the relationships among motivation, self-monitoring, and self-management. Educational Technology Research and Development 68(5): 2073-2093.

doi:10.1007/s11423-020-09747-8 